\title{
Influence of energy supplementation on associative effects in Nellore bulls on a tropical pasture during the rainy season
}

\section{Influência da suplementação energética nos efeitos associativos em touros Nelore em pastagem tropical durante o período das águas}

\author{
Mariane Stahlhöfer ${ }^{1 *}$; Ériton Egidio Lisboa Valente ${ }^{2}$; Lívia Vieira de Barros ${ }^{3}$; \\ Matheus Leonardi Damasceno'; Mariana Barbizan'; Brenda Vieira Rocha Melo4; \\ Stefani Natani dos Santos Arndt5; Sarah Stefany da Silva ${ }^{4}$
}

\section{Highlights}

Predicting how grain affects pasture use and livestock production is complex.

The use of concentrate supplements in pasture-based beef systems was analyzed.

Energy supplementation had a substitutive effect on pasture dry matter intake.

The increase in energy supplement intake did not affect body weight gain.

Supplementation reduced ruminal ammonia concentration.

\begin{abstract}
The objective of this study was to evaluate the influence of energy supplementation on associative effects between forage and concentrate supplements and on the performance of beef cattle on a tropical pasture during the rainy season. Twenty-eight Nellore bulls averaging 19 months of age and $325.2 \pm 4.1 \mathrm{~kg}$ were allotted to a completely randomized design and distributed into four paddocks of two hectares each with a tropical pasture for $84 \mathrm{~d}$. The treatments consisted of bulls on Urochloa brizantha cv. Xaraés pasture without concentrate supplementation or bulls on Urochloa brizantha cv. Xaraés pasture receiving concentrate supplementation at 15 (S15), 30 (S30) or 45\% (S45) of the total digestible nutrients (TDN) requirement.

1 PhD Students of Animal Science, Universidade Estadual do Oeste do Paraná, UNIOESTE, Marechal Cândido Rondon, PR, Brazil. E-mail: marianefj@gmail.com; matheusld31@gmail.com; maribarbizan94@gmail.com

2 PhD Prof., Animal Science, Graduate Faculty, UNIOESTE, Marechal Cândido Rondon, PR, Brazil. E-mail address: eritonvalente@yahoo.com.br

${ }^{3} \mathrm{PhD}$, Profa. of Animal Science, Graduate Faculty, Universidade Federal do Mato Grosso, UFMT Cuiabá, MT, Brazil. E-mail: liviavieiradebarros@gmail.com

${ }^{4}$ Animal Scientist, UNIOESTE, Marechal Cândido Rondon, PR, Brazil. E-mail: brendavrmelo@gmail.com; sarah. stefany07@hotmail.com

${ }^{5}$ M.e Student of Animal Science, UNIOESTE, Marechal Cândido Rondon, PR, Brazil. E-mail: stefaninatani1@hotmail. com

* Author for correspondence
\end{abstract}

Received: Nov. 24, 2020 - Approved: Apr. 01, 2021 
All bulls had ad libitum access to mineral supplementation. The amount and chemical composition of the supplement were adjusted every $28 \mathrm{~d}$. Forage and supplement intakes were evaluated in all animals using fecal markers. Crude protein: digestible organic matter ratio decreased with supplementation; consequently, the imbalance between dietary protein and energy increased. Forage intake decreased with increasing supplementation. The substitution rates of pasture for supplementary feed were $0.14,0.33$, and 0.46 for bulls from S15, S30, and S45 treatments, respectively. However, the apparent DM digestibility increased linearly with supplementation level. Supplementation improved the assimilation of ammonia- $\mathrm{N}$ in the rumen. Energy supplementation for Nellore bulls on tropical pastures during the rainy season provides excess energy relative to protein, resulting in a substitution effect of supplement intake on forage intake. Moreover, energy supplementation does not improve body weight gain. Protein sources should be added to supplements for balancing protein and energy levels, thereby reducing a likely substitution effect.

Key words: Beef cattle. Grazing. Productive performance.

\section{Resumo}

O objetivo deste trabalho foi avaliar a influência da suplementação energética nos efeitos associativos entre a forragem e suplemento concentrado e no desempenho de bovinos de corte em pasto tropical durante o período chuvoso. Vinte e oito touros da raça Nelore com idade média de 19 meses e 325,2 $\pm 4,1 \mathrm{~kg}$ foram alocados em delineamento inteiramente casualizado e distribuídos em quatro piquetes de dois hectares cada, com pasto tropical por 84 dias. Os tratamentos consistiram de touros em pastagem com Urochloa brizantha cv. Xaraés sem suplementação concentrada e touros em pastagem de Urochloa brizantha cv. Xaraés recebendo suplementação concentrada com 15 (S15), 30 (S30) ou 45\% (S45) da necessidade de nutrientes digestíveis totais (NDT). Todos os touros tiveram acesso ad libitum à suplementação mineral. A quantidade e a composição química do suplemento foram ajustadas a cada 28 dias. A ingestão de forragem e suplemento foi avaliada em todos os animais por meio de marcadores fecais. A relação proteína bruta: matéria orgânica digestível diminuiu com a suplementação, consequentemente, o desequilíbrio entre proteína e energia da dieta aumentou. O consumo de forragem diminuiu, com efeito substitutivo do consumo de pasto pelo suplemento de $0,14,0,33$ e 0,46 para touros dos tratamentos S15, S30 e S45, respectivamente. No entanto, a digestibilidade aparente da MS aumentou linearmente com o nível de suplementação. A suplementação melhorou a assimilação do nitrogênio amoniacal no rúmen. A suplementação energética para touros Nelore em pastagens com pasto tropical durante a estação chuvosa fornece excesso de energia em relação à proteína, resultando em um efeito de substituição do consumo de forragem por suplemento. Além disso, a suplementação energética não melhora o ganho de peso corporal. Fontes de proteína devem ser adicionadas aos suplementos para equilibrar os níveis de proteína e energia, diminuindo um provável efeito de substituição.

Palavras-chave: Bovinos de corte. Desempenho produtivo. Pastejo.

\section{Introduction}

Beef cattle on tropical pastures usually do not reach their genetic potential even during the rainy season (Reis, Ruggieri, Oliveira,
Azenha, \&Casagrande,2012)asaconsequence of a nutritional imbalance (Detmann, Valente, Batista, \& Huhtanen, 2014b). During the rainy season, nitrogen availability for cattle is not the primary concern in feed planning because 
forages typically have high levels of rapidlydegraded nitrogen compounds and high levels of slowly-degradable carbohydrates (Koscheck et al., 2011). Therefore, the lack of synchrony between protein and carbohydrate degradation may limit rumen microbial growth (Hackmann \& Firkins, 2015; V. A. C. Costa et al., 2011).

When protein degradation rate exceeds the rate of carbohydrate degradation, the absorption of ammonia and oxidation of amino acids in the rumen increase (Bento, Azevedo, Detmann, \& Mantovani, 2015). Therefore, an imbalance between protein and carbohydrate sources may decrease nitrogen use efficiency and limit animal performance (Detmann et al., 2014b).

The addition of non-fiber carbohydrates (NFC) to the diet increases nitrogen assimilation by improving microbial growth in the rumen (Lu, Shen, \& Shen, 2019). However, an additional starch supply may intensify the competition between the microbial population, which in turn could decrease fiber degradation (Lazzarini et al., 2016). Therefore, grain supplementation could modify forage utilization by cattle thus inducing associative effects on nutrient utilization efficiency (Detmann et al., 2014b).

As the proportion of grain increases in the diet, the body weight gain usually increases as well (E. E. L. Valente, Paulino, Detmann, Valadares, \& Lopes, 2013). On the other hand, the forage intake may reduce as a result of the associative effect in mixed diets (E. E. L. Valente et al., 2014). However, it is challenging to predict how the associative effects may occur and how they would affect the utilization of dietary nutrients. There are still few studies on the interaction between grain and forage sources. Although the associative effects are usual in grazing cattle receiving supplementary concentrates, these effects are frequently not considered during diet evaluation [e.g., (National Research Council [NRC], 2000; Valadares, Marcondes, Chizzotti, \& Paulino, 2010). Thus, the objective of this study was to evaluate the influence of energy supplementation on associative effects between forage and concentrate supplements and on the performance of beef cattle grazing a tropical pasture during the rainy season.

\section{Material and Methods}

This study was approved by the Brazilian Ethics Committee on Animal Use (CEUA/Unioeste - Protocol $n^{\circ}$ 58/17), in accordance with the ethical principles of animal experimentation established by the National Council of Animal Experimentation Control (CONCEA).

The study was carried out between October 2016 and January 2017 in the municipality of Entre Rios do Oeste, Paraná,

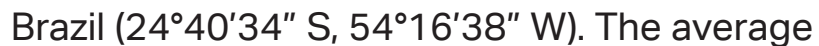
temperature recorded was $23.89 \pm 0.08{ }^{\circ} \mathrm{C}$, with a rainfall index of $188 \mathrm{~mm}$.

Twenty-eight Nellore bulls averaging 19 months of age and $325.2 \pm 4.1 \mathrm{~kg}$ were used. The experimental period was divided into $14 \mathrm{~d}$ for adaptation to diets and $84 \mathrm{~d}$ for data collection. Bulls were kept on an 8 ha $^{-1}$ pasture with Urochloa brizantha cv. Xaraés, divided into four paddocks of two hectares each. Bulls were rotated among paddocks of similar pasture composition every seven days for allowing each group to graze each paddock for the same period. 
Bulls received one of the following treatments: Urochloa brizantha cv. Xaraés pasture without concentrate supplementation (SO) or bulls with Urochloa brizantha cv. Xaraés pasture receiving concentrate supplementation at 15 (S15), 30 (S30) or $45 \%$ (S45) of the total digestible nutrients (TDN) requirement. All bulls had ad libitum access to mineral supplement. The amount and chemical composition of the supplement were adjusted every 28 d (Figure 1; Table 1). Crude protein (CP) levels in supplements were calculated to meet the protein requirements of cattle.
The TDN and CP requirements were calculated using the BR-CORTE database - Nutritional Requirements of Zebu and crossbred cattle (Valadares et al., 2010). We used an average daily gain (ADG) of $0.9 \mathrm{~kg}$ to calculate the nutrient requirements in the first $28 \mathrm{~d}$, while the ADG obtained from d 0 to 28 was used in the following calculations. Urea was added to the supplement to provide $30 \% \mathrm{~N}$ of the supplement (Table 1). The supplements were offered daily at 11 a.m.

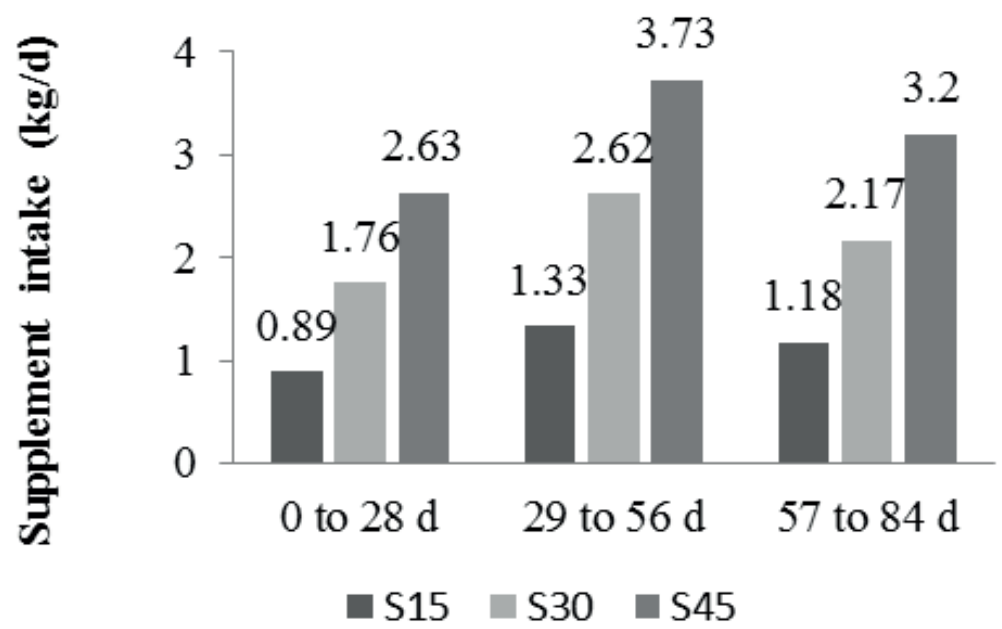

Figure 1. Supplement intake of bulls supplemented with 15 (S15), 30 (S30) or 45\% (S45) of total digestible nutrients requirement during the experimental period. 
Table 1

Ingredients of the supplement and chemical composition of supplements and pasture

\begin{tabular}{|c|c|c|c|c|}
\hline \multirow[b]{2}{*}{ Ingredients } & \multicolumn{3}{|c|}{ TDN requirement supplied (\%) } & \multirow[t]{2}{*}{ Pasture $^{1}$} \\
\hline & 15 & 30 & 45 & \\
\hline Ground corn, \% & 77.00 & 89.00 & 95.00 & \\
\hline Soybean meal, \% & 20.00 & 9.00 & 4.00 & \\
\hline Urea, \% & 2.30 & 1.70 & 1.40 & \\
\hline Ammonium sulfate, $\%$ & 0.20 & 0.20 & 0.20 & \\
\hline \multicolumn{5}{|l|}{ Chemical composition } \\
\hline Dry matter, \% & 91.10 & 91.55 & 91.75 & $91.61^{2}$ \\
\hline Organic matter, \% of DM & 95.13 & 96.38 & 97.02 & 91.64 \\
\hline Crude protein, \% of DM & 22.19 & 16.64 & 13.62 & 11.02 \\
\hline aNDF, $\%$ of $\mathrm{DM}^{3}$ & 10.43 & 9.86 & 9.53 & 55.91 \\
\hline TDN, \% of DM & $81.67^{4}$ & $83.00^{4}$ & $83.33^{4}$ & $51.01^{5}$ \\
\hline
\end{tabular}

${ }^{1}$ Urochloa brizantha cv. Xaraés; ${ }^{2}$ Dry matter calculated after pre-drying the forage; ${ }^{3}$ Ash- and protein-free neutral detergent fiber; ${ }^{4}$ Total digestible nutrients estimated according to Valadares et al. (2010); ${ }^{5}$ Calculated as described by the NRC (2001).

The forage sward height, forage mass, and forage accumulation rate were obtained every 28 days. Forage sward height was determined by the distance from the soil to the most recent fully expanded leaf using a graduated ruler, represented by the average of 100 random points per paddock. Forage mass was evaluated by cutting six areas of $0.25 \mathrm{~m}^{2}$ at $1 \mathrm{~cm}$ above the ground level in each paddock. Forage accumulation rate was evaluated using three $1 \mathrm{~m}^{2}$ exclusion cages placed randomly in each paddock. Forage accumulation was calculated by subtracting the forage mass (kg of $\mathrm{DM} \mathrm{m}^{2}$ ) at the beginning of the evaluation period from the forage mass inside the cages after $28 \mathrm{~d}$. Forage accumulation rate $\left(\mathrm{kg} \mathrm{ha}^{-1}\right.$ $\mathrm{d}^{-1}$ ) was calculated by dividing the forage accumulation by the time of evaluation ( $28 \mathrm{~d}$ ).

Pasture samples were taken every 14 days using the handle-plucking method to evaluate the chemical composition of ingested forage. Additionally, pasture samples were individually taken at d 43 using the same method to estimate the intake and digestibility of bulls from each treatment.

From d 38 to d 45, an assay including all animals was performed to estimate nutrient intake and digestibility. Fecal dry matter (DM) output was determined using titanium dioxide as an external marker. Titanium dioxide was packed in paper bags and introduced into the esophagus by a flexible rubber tube. The individual intake of the supplement was evaluated by mixing approximately $15 \mathrm{~g} / \mathrm{d}$ of chromium oxide per bull to the supplement offered to each group. Markers were offered once daily at 11 a.m. from d 38 to $\mathrm{d} 44$. Forage intake was estimated using the indigestible neutral detergent fiber (iNDF) as an internal marker. After five days of adaptation, fecal samples were collected at 4 p.m. on d 43 , at midday on d 44, and 8 a.m. on d 45 . 
Fecal output $(\mathrm{kg})$ was estimated by dividing the concentration of titanium dioxide supplied daily ( $\mathrm{g} / \mathrm{d}$ ) by the marker concentration in the feces $(\mathrm{kg} / \mathrm{kg})$. The individual supplement intake was estimated using chromium oxide as an external marker according to the following equation:

$$
\text { DMIS }=\frac{\text { FO } \times \text { MCF }}{\text { MCS }}
$$

where DMIS is the dry matter intake of supplement $(\mathrm{kg} / \mathrm{d})$, FO is the fecal output $(\mathrm{kg} / \mathrm{d})$, MCF is the marker concentration in the feces $(\mathrm{kg} / \mathrm{kg})$, and MCS is the marker concentration in the supplement $(\mathrm{kg} / \mathrm{kg})$.

Dry matter intake (DMl, kg/d) was estimated using the iNDF as an internal marker and calculated by the following equation:

$$
\mathrm{DMI}=\frac{\left[\left(\mathrm{FO}_{\mathrm{x}} \mathrm{iNDF}_{\text {feces }}\right)-\mathrm{iNDF}_{\text {supplement }}\right]}{\mathrm{iNDF}_{\text {forage }}}+\text { DMIS }
$$

where FO is the fecal output $(\mathrm{kg} / \mathrm{d}), \mathrm{iNDF}_{\text {feces }}$ is the iNDF concentration in the feces $(\mathrm{kg} /$ $\mathrm{kg})$, iNDF $_{\text {supplement }}$ is the iNDF concentration in the supplement $(\mathrm{kg}), \mathrm{iNDF}_{\text {forage }}$ is the iNDF concentration in the forage $(\mathrm{kg} / \mathrm{kg})$, and DMIS is the dry matter intake of supplement.

The substitution rate of forage for supplementary feed was calculated by the difference between forage intake (kg of $\mathrm{DM} / \mathrm{kg}$ of BW) of non-supplemented bulls (SO) and supplemented bulls, divided by the supplement intake ( $\mathrm{kg}$ of $\mathrm{DM} / \mathrm{kg}$ of $\mathrm{BW}$ ). Positive values indicate reduced forage intake with supplementation, while a negative coefficient indicates an increase in forage intake with supplementation.

Samples of forage, feces, and ingredients were oven-dried at $55^{\circ} \mathrm{C}$ for 72 hours and ground to passa $1 \mathrm{~mm}$ screen, except for iNDF determinations, in which samples were ground to $2 \mathrm{~mm}$ diameter. Samples were analyzed for DM (method INCT-CA G-003/1), CP (method INCT-CA N-001/1), organic matter (method INCT-CA M-001/1), and ether extract (method INCT-CA G-004/1) as described by (Detmann et al., 2012). Samples were treated with thermostable $\alpha$-amylase without sodium sulfite and corrected for ash residue and residual nitrogen compounds to estimate the ash and protein-free neutral detergent fiber (aNDF) content (method INCT-CA F-002/1) (Detmann et al., 2012). The iNDF content (used as an internal marker) in feed and fecal samples was evaluated using F57 (Ankom, Macedon, NY, USA) filter bags incubated in the rumen for 288 hours (T. N. P. Valente et al., 2011). Total digestible nutrient (TDN) content was calculated as described by the (NRC, 2001). Fecal samples were also analyzed for chromium (Williams, David, \& lismaa, 1962) and titanium dioxide (Myers, Ludden, Nayigihugu, \& Hess, 2004) concentration using atomic absorption and colorimetric methods, respectively.

Rumen fluid, blood and urine samples were collected $4 \mathrm{~h}$ before (in the morning) and $4 \mathrm{~h}$ after (in the afternoon) supplementation (11 a.m.) at d 45 and 46. Rumen fluid was collected via esophageal tubing with the aid of a vacuum pump. An aliquot of $50 \mathrm{~mL}$ per bull was taken, then $1 \mathrm{~mL}$ of $\mathrm{H}_{2} \mathrm{SO}_{4}$ (50\%) was added to the sampled material and kept at $-20^{\circ} \mathrm{C}$. Subsequently, a $10 \mathrm{~mL}$ blood sample was taken through the jugular vein. Blood was centrifuged at $2,000 \mathrm{~g}$ for $15 \mathrm{~min}$ to obtain the serum, which was kept at $-20^{\circ} \mathrm{C}$. Urine spot samples were collected following spontaneous urination. A $10 \mathrm{~mL}$ urine aliquot was taken, then $40 \mathrm{~mL}$ of $\mathrm{H}_{2} \mathrm{SO}_{4}(0.036 \mathrm{~N})$ was added and kept at $-20^{\circ} \mathrm{C}$. 
Urine and serum samples were analyzed for urea concentration using a commercial kit (Gold Analisa, Belo Horizonte, MG, Brazil). Rumen fluid was analyzed for ruminal ammonia-nitrogen concentration (RAN) using the colorimetric method (Chaney \& Marbach, 1962) by replacing phenol with sodium salicylate (Felix \& Cardoso, 2004).

We analyzed urinary creatinine concentration using commercially available test kits (Analisa ${ }^{\circledR}$ Belo Horizonte, MG, Brazil) by the alkaline picrate method. Daily urine volume was calculated by the relationship between the daily creatinine excretion and its concentration in spot samples (Silva et al., 2012):

\section{$C E=0.0345 \times B W^{0.9491}$}

where CE is creatinine excretion (g/d), and BW is body weight $(\mathrm{kg})$.

The ADG of bulls was calculated by the difference between the final and initial body weights, after a fasting period of 14 hours, divided by the number of experimental days (84). Subcutaneous fat thickness (SFT) was evaluated by ultrasound on a transverse section of the Longissimus dorsi muscle (between T12 and T13 thoracic vertebrae), while the P8 fat thickness (P8FT) was evaluated on a longitudinal section of Biceps femoris located between the hooks and pin bones. Ultrasound evaluations were always performed on the left side of each animal in the first and the last day of the experiment. We used an Aquila Ultrasound with a linear transducer of $18 \mathrm{~cm}$ and a frequency of 3.5 Mhz. Ultrasound images were analyzed in the Sketchup ${ }^{\circledR}$ (Trimble Inc.).

The time spent grazing was evaluated from d 22 to $d 25, d 50$ to $d 53$ and d 78 to $d 81$, from 7 a.m. to 7 p.m. by visual observations.
Observers were positioned simultaneously at two fixed points, and the observation was performed using binoculars. The distance of the observer from the bulls ranged from 20 to $200 \mathrm{~m}$. Grazing time was recorded continuously.

All data were analyzed using the MIXED procedure of SAS (SAS University Edition). One replicate in the $S 15$ treatment was lost. All variables were evaluated by linear and quadratic effects using polynomials contrasts. Data relative to the rumen, blood, and urine variables were analyzed as repeated measures over time according to the following model (Kaps \& Lamberson, 2004):

$$
Y_{i j k}=\mu+S_{i}+T_{j}+(S x T)_{i j}+A_{k}+e_{i j k}
$$

where $Y_{i j k}$ is the dependent variable; $\mu=$ the overall mean; $S_{i}$ is the fixed effect of the $i_{\text {th }}$ supplementation level; $T_{j}$ is the fixed effect of the $j_{\text {th }}$ sampling time; $(S x T)_{i j}$ is the interaction between main effects; Ak is the random effect of the kth bull; and $e_{i j k}$ is the random error associated with $\mathrm{Y}_{\mathrm{ijk}}$ distributed as $\mathrm{e}_{\mathrm{ijk}} \sim \mathrm{N}\left(0, \sigma e^{2}\right)$.

The adequacy of the models and the best covariance structures were evaluated using the corrected Akaike's information criterion. All variance components were estimated using the restricted maximum likelihood method. All statistical evaluations were performed using a significance level set at 0.05 .

\section{Results and Discussion}

The mean forage mass was $4894 \pm 441$ $\mathrm{kg}$ of DM ha-1, while forage accumulation rate was $85.3 \pm 4.2 \mathrm{~kg}$ of DM ha-1 $\mathrm{d}^{-1}$. The mean sward heightwas $40 \pm 2.4 \mathrm{~cm}$. Forageintakedecreased linearly $(P<0.05)$ with supplementation level 
(Table 2). The substitution rates of pasture for supplementary feed were 0.14, 0.33, and 0.46 for bulls from S15, S30, and S45 treatments, respectively. Intakes of ash- and protein-free neutral detergent fiber (aNDF) decreased linearly $(P<0.05)$ with energy supplementation. However, intakes of DM (P >
0.05), CP ( $P>0.05), D O M(P>0.05)$ and TDN $(P$ $>0.05)$ were similar between bulls fed different supplementation levels (Table 2). The CP:DOM ratios were 220, 254, 245, and $206 \mathrm{~g}$ of CP/kg of DOM for bulls from S0, S15, S30, and S45 treatments, respectively.

\section{Table 2}

Intakes of dry matter (DM), DM of forage (DMF), DM of supplement (DMS), crude protein (CP), ashand protein-free neutral detergent fiber (aNDF), digestible organic matter (DOM) and total digestible nutrients (TDN) according to the TDN requirement supplied by the supplement

\begin{tabular}{|c|c|c|c|c|c|c|c|}
\hline \multirow[b]{2}{*}{ Item } & \multicolumn{4}{|c|}{ TDN requirement supplied (\%) } & \multirow[b]{2}{*}{ SE } & \multicolumn{2}{|c|}{ Contrast } \\
\hline & 0 & 15 & 30 & 45 & & $L$ & $\bar{Q}$ \\
\hline $\mathrm{DM}, \mathrm{g} / \mathrm{kg}$ of $\mathrm{BW}$ & 20.93 & 21.37 & 20.54 & 20.47 & 1.15 & 0.659 & 0.827 \\
\hline DMF, g/kg of BW & 20.93 & 17.95 & 14.11 & 11.35 & 0.77 & $<0.001$ & 0.888 \\
\hline DMS, $g / k g$ of BW & 0.00 & 3.42 & 6.34 & 9.12 & 0.62 & $<0.001$ & 0.610 \\
\hline $\mathrm{CP}, \mathrm{g} / \mathrm{kg}$ of $\mathrm{BW}$ & 2.51 & 3.01 & 2.83 & 2.67 & 0.17 & 0.714 & 0.071 \\
\hline aNDF, $\mathrm{g} / \mathrm{kg}$ of $\mathrm{BW}$ & 13.12 & 11.61 & 9.48 & 7.99 & 0.51 & $<0.001$ & 0.992 \\
\hline DOM, g/kg of BW & 11.41 & 11.82 & 11.50 & 12.95 & 0.60 & 0.111 & 0.403 \\
\hline TDN, $\mathrm{g} / \mathrm{kg}$ of BW & 11.34 & 11.13 & 11.26 & 12.85 & 0.63 & 0.100 & 0.172 \\
\hline
\end{tabular}

$\mathrm{L}=$ linear contrast; $\mathrm{Q}=$ quadratic contrast.

Apparent DM digestibility increased linearly $(P<0.05)$ with supplementation (Table 3). On the other hand, supplementation level had a quadratic effect on apparent digestibility of $\mathrm{CP}$ and aNDF $(\mathrm{P}<0.05$, Table 3$)$.

Table 3

Apparent digestibility of dry matter (DM), crude protein (CP), and ash- and protein-free detergent fiber (aNDF) according to the TDN requirement supplied by the supplement

\begin{tabular}{|c|c|c|c|c|c|c|c|}
\hline \multirow[b]{2}{*}{ Item } & \multicolumn{4}{|c|}{ TDN requirement supplied (\%) } & \multirow[b]{2}{*}{ SE } & \multicolumn{2}{|c|}{ Contrast } \\
\hline & 0 & 15 & 30 & 45 & & L & $Q$ \\
\hline $\mathrm{DM}, \%$ & 54.22 & 56.92 & 56.91 & 63.05 & 0.92 & $<0.001$ & 0.076 \\
\hline $\mathrm{CP}, \%$ & 63.62 & 65.98 & 68.87 & 63.67 & 1.05 & 0.511 & 0.002 \\
\hline aNDF, \% & 68.85 & 66.06 & 63.50 & 67.05 & 0.92 & 0.059 & 0.002 \\
\hline
\end{tabular}

$\mathrm{L}=$ linear contrast; $\mathrm{Q}=$ quadratic contrast. 
Urinary nitrogen excretion (UNE) and serum urea nitrogen (SUN) were affected $(P<0.05)$ by treatment, sampling time, and treatment $x$ sampling time interaction (Table 4). Although the ruminal ammonia-nitrogen concentration (RAN) was not influenced by the treatment $x$ sampling time interaction $(P>$ 0.05), RAN was affected $(P<0.05)$ by treatment and sampling time.

Table 4

Urinary nitrogen excretion (UNE), serum urea nitrogen (SUN) and ruminal ammonia-nitrogen (RAN) concentration according to the TDN requirement supplied by the supplement

\begin{tabular}{|c|c|c|c|c|c|c|c|c|}
\hline \multirow[b]{2}{*}{ Item } & \multicolumn{4}{|c|}{ TDN requirement supplied (\%) } & \multirow[b]{2}{*}{ SE } & \multicolumn{3}{|c|}{ P-value } \\
\hline & 0 & 15 & 30 & 45 & & Treatment & Time & Tr*time \\
\hline UNE, g/d & 64.41 & 92.82 & 67.11 & 83.47 & 2.663 & $<0.001$ & $<0.001$ & 0.002 \\
\hline SUN, mg/dL & 12.88 & 18.66 & 14.40 & 15.00 & 0.599 & $<0.001$ & $<0.001$ & $<0.001$ \\
\hline RAN, mg/dL & 9.29 & 11.68 & 9.42 & 8.18 & 0.550 & 0.002 & 0.004 & 0.145 \\
\hline
\end{tabular}

Treatment: effect of treatment; time: effect of sampling time; Tr*time: effect of the interaction between treatment and sampling time.

Energy supplementation had a quadratic effect $(P<0.05)$ on UNE and SUN in the afternoon (Table 5). Bulls from the S15 treatment had higher $(P<0.05)$ UNE and SUN in both sampling times. The UNE, SUN, and RAN values were lower $(P<0.05)$ in the morning than in the afternoon.

Table 5

Interaction between supplementation and sampling time on urinary nitrogen excretion (UNE) and serum urea nitrogen (SUN)

\begin{tabular}{|c|c|c|c|c|c|c|c|}
\hline \multirow[b]{2}{*}{ Item } & \multicolumn{4}{|c|}{ TDN requirement supplied (\%) } & \multirow[b]{2}{*}{ SE } & \multicolumn{2}{|c|}{ Contrast } \\
\hline & 0 & 15 & 30 & 45 & & L & $Q$ \\
\hline \multicolumn{8}{|c|}{ Morning } \\
\hline UNE, g/d & 59.41 & 78.83 & 59.94 & 70.82 & 2.29 & 0.117 & 0.080 \\
\hline SUN, mg/dL & 11.80 & 14.85 & 13.02 & 13.26 & 0.72 & 0.413 & 0.067 \\
\hline \multicolumn{8}{|c|}{ Afternoon } \\
\hline UNE, g/d & 69.40 & 106.75 & 73.05 & 91.59 & 2.97 & 0.020 & 0.005 \\
\hline SUN, mg/dL & 13.87 & 22.44 & 16.07 & 16.74 & 0.69 & 0.453 & $<0.001$ \\
\hline
\end{tabular}

Morning: 4h before supplementation; Afternoon: $4 \mathrm{~h}$ after supplementation; $\mathrm{L}=$ linear contrast; $\mathrm{Q}=$ quadratic contrast. 
Supplementation level did not affect the ADG $(P>0.05)$, final BW $(P>0.05)$ and body weight gain $(P>0.05)$ of bulls (Table 6$)$.
Subcutaneous fat thickness and PG8 were not affected $(P>0.05)$ by supplementation (Table 6).

Table 6

Average daily weight gain (ADG), final body weight (BWf), body weight gain (BWG), initial subcutaneous fat thickness (SFTi), final subcutaneous fat thickness (SFTf), gain of subcutaneous fat thickness (SFTg), gain of subcutaneous fat thickness per $100 \mathrm{~kg}$ of body weight (SFT_100), initial P8 fat thickness (P8FTi), final P8 fat thickness (P8FTf), gain of P8 fat thickness (P8FTg), and gain of P8 fat thickness per $100 \mathrm{~kg}$ of body weight (P8FTg_100) according to the TDN requirement supplied by the supplement

\begin{tabular}{|c|c|c|c|c|c|c|c|}
\hline \multirow[b]{2}{*}{ Item } & \multicolumn{4}{|c|}{ TDN requirement supplied (\%) } & \multirow[b]{2}{*}{ SE } & \multicolumn{2}{|c|}{ Contrast } \\
\hline & 0 & 15 & 30 & 45 & & L & Q \\
\hline ADG, kg & 1.17 & 1.27 & 1.29 & 1.26 & 0.05 & 0.184 & 0.251 \\
\hline BWf, kg & 426.50 & 433.78 & 435.23 & 433.43 & 4.20 & 0.238 & 0.292 \\
\hline BWG, kg & 99.00 & 106.28 & 107.73 & 105.93 & 4.20 & 0.238 & 0.292 \\
\hline $\mathrm{SFTi}, \mathrm{mm}$ & 0.49 & 0.30 & 0.70 & 0.40 & 0.25 & 0.928 & 0.790 \\
\hline SFTf, mm & 1.93 & 3.18 & 2.12 & 2.87 & 0.28 & 0.153 & 0.372 \\
\hline SFTg, mm & 1.44 & 2.88 & 1.42 & 2.48 & 0.32 & 0.231 & 0.561 \\
\hline SFTg_100, mm/100kg & 0.46 & 0.74 & 0.49 & 0.66 & 0.07 & 0.258 & 0.455 \\
\hline P8FTi, mm & 1.91 & 1.95 & 1.68 & 1.90 & 0.13 & 0.576 & 0.480 \\
\hline P8FTf, mm & 4.1 & 4.6 & 4.1 & 4.31 & 0.38 & 0.928 & 0.698 \\
\hline P8FTg, mm & 2.19 & 2.65 & 2.42 & 2.41 & 0.34 & 0.753 & 0.483 \\
\hline P8FTg_100, m/100kg & 0.38 & 0.46 & 0.43 & 0.41 & 0.08 & 0.848 & 0.536 \\
\hline
\end{tabular}

$\mathrm{L}=$ linear contrast; $\mathrm{Q}=$ quadratic contrast.

Diurnal grazing time decreased linearly $(P<0.05)$ with supplementation, averaging $4.58,4.06,3.5$ and $2.95 \mathrm{~h} / \mathrm{d}$ for bulls from SO, S15, S30, and S45 treatments, respectively. Grazing time decreased linearly with energy supplementation, with reductions of $11.4,23.6$ and $35.6 \%$ for bulls from treatments S15, S30, and S45, respectively, relative to the control.

Forage mass was considerably high, thus ensuring a forage allowance above $10 \%$ BW and not limiting forage selection by cattle. The mean forage $\mathrm{CP}$ content above $11 \%$ may have been sufficient to meet the requirements and boost the growth of rumen microorganisms, thereby improving fiber digestibility and optimizing forage utilization (Detmann, Paulino, Valadares, \& Huhtanen, 2014a; N. L. Costa et al., 2015). However, the dietary CP content was lower than the recommended level of $14.5 \% \mathrm{CP} / \mathrm{kg}$ of DM for maximum feed intake (Detmann et al., 2014b).

Although diets were formulated to have similar levels of $\mathrm{CP}$, the differences in CP intake between supplemented bulls was probably due to the associative effects induced by supplementation, which decreased 
forage intake, since the substitution effect is not considered when estimating nutrient requirements for cattle in the Nutritional Requirements of Zebu and crossbred cattle database (Valadares et al., 2010). The CP fraction available to ruminants is lower in forage than in grains, and an increase of dietary crude protein above the recommended level may improve the utilization of dietary nutrients (Figueiras et al., 2015). In all treatments, the CP:DOM ratio was below the recommended level of 250 - $288 \mathrm{~g}$ of CP/kg of DOM for maximum forage intake in tropical pastures (Detmann et al., 2014b), even adjusting the $\mathrm{CP}$ level to meet the requirements of bulls. Nutrient requirement systems e. g. (Valadares et al., 2010) usually do not consider all the complexity of the interaction between dietary components for cattle fed diets containing forage and concentrate supplements. Therefore, a nutritional imbalance associated with excess energy relative to available $\mathrm{CP}$ may occur.

The linear reduction of forage intake with increasing supplementation level may be due to changes in rumen microorganisms, thereby decreasing rumen dynamics of NDF. Although physical regulation plays an essential role in feed intake (Wanapat, Gunun, Gunun, \& Kang, 2013), the microbial interaction in the rumen may be the major regulator of feed intake in grazing cattle receiving low-protein supplements (Lazzarini et al., 2013).

The addition of grains to the diet of cattle grazing tropical pastures usually decreases fiber digestibility (E. E. L. Valente et al., 2014). The intake of starch from the supplement increases the competition of rumen microorganisms for substrates, and then the NDF digestibility reduces because fibrolytic microorganisms have low competitive capacity (Lazzarini et al., 2016). Although supplementation had a negative effect on fiber digestibility, supplementary feed improved the DM digestibility in bulls (Table 3) due to the increase of NFC intake, which has inherently high digestibility (Tebot, Cajarville, Repetto, \& Cirio, 2012).

Reductions of RAN concentration in treatment S45 (supplemented bulls) indicate that the supply of starch may have increased ammonia utilization in the rumen. The addition of supplementary energy for rumen microorganisms improves fermentation efficiency, increasing the assimilation of ammonianitrogenintomicrobialprotein(Franco et al., 2017). RAN concentrations lower than $13 \mathrm{mg} / \mathrm{dL}$, suggested as the level associated with maximum DOM intake (Detmann et al., 2014b), indicate that the balance between CP and energy was not optimal for maximum feed intake and digestibility.

Supplementation aims to improve animal performance by increasing the supply of energy. However, the associative effects between pasture forages and concentrate supplements prevented any changes in cattle performance with supplementation. The additional energy from the supplements did not increase available energy for animal growth, and fat deposition rather increased the imbalance between protein and energy ratio. This imbalance affects feed intake and growth (Detmann et al., 2014a). Thus, the lack of improvements in cattle performance probably occurred due to the lack of protein relative to energy content rather than the lack of energy itself for animal metabolism. The substitution effect probably was induced by the starch from the supplement. 
Although energy supplementation may increase the performance of grazing beef cattle during the rainy season (Pesqueira-Silva et al., 2015), it usually reduces the forage intake (V. A. C. Costa et al., 2011). Moreover, energy supplementation at moderate/high levels usually decreases the time spent grazing due to the lower forage intake (E. E. L. Valente et al., 2013). This fact may explain the reduction in pasture intake and grazing time observed in the present study. The additional energy provided by the starch through supplementation promotes a substitute effect of pasture intake by the supplement, consequently reducing grazing time (E. E. L. Valente et al., 2014).

\section{Conclusion}

Energy supplementation for Nellore bulls on a tropical pasture during the rainy season provides excess energy relative to protein, resulting in a substitution effect of supplement intake on forage intake. Therefore, energy supplementation does not improve body weight gain and fat deposition. Protein sources should be added to supplements for balancing protein and energy levels, thereby reducing a likely substitution effect.

\section{Acknowledgments}

This study was financed in part by the Coordenação de Aperfeiçoamento de Pessoal de Nível Superior - Brasil (CAPES) Finance Code 001 and the Conselho Nacional de Pesquisa e Desenvolvimento Científico e Tecnológico (CNPq).

\section{References}

Bento, C. B. P., Azevedo, A. C., Detmann, E., \& Mantovani, H. C. (2015). Biochemical and genetic diversity of carbohydratefermenting and obligate amino acidfermenting hyper-ammonia-producing bacteria from Nellore steers fed tropical forages and supplemented with casein. BMC Microbiology, 15(28), 1-15. doi: 10. 1186/s12866-015-0369-9

Chaney, A. L., \& Marbach, E. P. (1962). Modified reagents for determination of urea and ammonia. Clinical Chemistry, 8(2), 130132. doi: $10.1021 / A C 60252 A 045$

Costa, N. L., Monteiro, A. L. G., Silva, A. L. P., Moraes, A., Giostri, A. F., Stivari, T. S. S., \& Pin, E. A. (2015). Considerações sobre a degradação da fibra em forragens tropicais associada com suplementos energéticos ou nitrogenados. Archivos de Zootecnia, 64(R), 31-34.

Costa, V. A. C., Detmann, E., Paulino, M. F., Valadares, S. C., Fo., Carvalho, I. P., \& Monteiro, L. P. (2011). Consumo e digestibilidade em bovinos em pastejo durante o período das águas sob suplementação com fontes de compostos nitrogenados e de carboidratos. Revista Brasileira de Zootecnia, 40(8), 17881798. doi: 10.1590/S1516-35982011000 800024

Detmann, E., Paulino, M. F., Valadares, S. C., F., \& Huhtanen, P. (2014a). Nutritional aspects applied to grazing cattle in the tropics: a review based on Brazilian results. Semina: Ciências Agrárias, 35(4), 2829-2854. doi: 10.5433/1679-0359.2014v35n4Suplp2 829 
Detmann, E., Souza, M. A., Valadares, S. C., F., Queiroz, A. C., Berchielle, T. T., Saliba, E. O. S., \& Azevedo, J. A. G. (2012). Métodos para análise de alimentos. Visconde do Rio Branco, MG: Suprema.

Detmann, E., Valente, É. E. L., Batista, E. D., \& Huhtanen, P. (2014b). An evaluation of the performance and efficiency of nitrogen utilization in cattle fed tropical grass pastures with supplementation. Livestock Science, 162(), 141-153. doi: 10.1016/j. livsci.2014.01.029

Felix, E. P., \& Cardoso, A. A. (2004). Amônia (NH3) atmosférica: Fontes, transformação, sorvedouros e métodos de análise. Quimica Nova, 27(1), 123-130. doi: 10.15 90/S0100-40422004000100022

Figueiras, J. F., Detmann, E., Valadares, S. C., Fo., Paulino, M. F., Batista, E. D., Rufino, L. M. A., \& Franco, M. O. (2015). Desempenho nutricional de bovinos em pastejo durante o período de transição seca-águas recebendo suplementação proteica. Archivos de Zootecnia, 64(247), 269-276. doi: 10.1590/S0100204X2009001100023

Franco, M. O., Detmann, E., Valadares, S. C., Fo., Batista, E. D., Rufino, L. M. A., Barbosa, M. M., \& Lopes, A. R. (2017). Intake, digestibility, and rumen and metabolic characteristics of cattle fed low-quality tropical forage and supplemented with nitrogen and different levels of starch. Asian-Australasian Journal of Animal Sciences, 30(6), 797803. doi: 10.5713/ajas.160629

Hackmann, T. J., \& Firkins, J. L. (2015). Maximizing efficiency of rumen microbial protein production. Frontiers in Microbiology, 6(465), 1-16. doi: 10.3389/ fmicb.2015.00465
Kaps, M., \& Lamberson, W. (2004). Repeated measures. In, M. Kaps \& W. Lamberson (Eds.), Biostatistics for animal science (pp. 365-383). Wallingford, CT: CABI Publishing.

Koscheck, J. F. W., Zevoudakis, J. T., Carvalho, D. M. G., Cabral, L. S., Amorim, K. P., Silva, R. G. F., \& Silva, R. P. (2011). Suplementação de bovinos de corte em sistema de pastejo. Uniciências, 15(1), 377-412. doi: 10.17921/1415-5141.2011v15n1p\%25p

Lazzarini,Í.,Detmann, E.,Paulino, M.F., Valadares, S. C., Fo., Valadares, R. F. D., Oliveira, F. A., \& Reis, W. L. S. (2013). Nutritional performance of cattle grazing on lowquality tropical forage supplemented with nitrogenous compounds and/or starch1. Revista Brasileira de Zootecnia, 42(9), 664-674. doi: 10.1590/S1516-35982013 000900009

Lazzarini, Í., Detmann, E., Valadares, S. C., Fo., Paulino, M. F., Batista, E. D., Rufino, L. M. A., \& Franco, M. O. (2016). Nutritional performance of cattle grazing during rainy season with nitrogen and starch supplementation. Asian-Australasian Journal of Animal Sciences, 29(8), 11201128. doi: 10.5713/ajas. 15.0514

Lu, Z., Shen, H., \& Shen, Z. (2019). Effects of Dietary-SCFA on microbial protein synthesis and urinal Urea-N excretion are related to microbiota diversity in rumen. Frontiers in Physiology, 10(1079), 1-13. doi: 10.3389/fphys.2019.01079

Myers, W.D., Ludden, P.A., Nayigihugu, V.,\&Hess, B. W. (2004). Technical note: a procedure for the preparation and quantitative analysis of samples for titanium dioxide. Journal of Animal Science, 82(1), 179183. doi: $10.2527 / 2004.821179 x$ 
National Research Council (2000). Requirements of beef cattle (7nd ed.). Washington, D.C: Nutrients Requeriments of Beef Cattle. Natl. Acad. Press.

National Research Council (2001). Requirements of dairy cattle (7nd ed.). Washington, D.C: Nutrients Requirements of Dairy Cattle. Natl. Acad. Press.

Pesqueira-Silva,L.C.R.,Zervoudakis,J.T.,Araújo, C. V., Cabral, L. S., Hatamoto-Zervoudakis, L. K., Oliveira, A. A., \& Silva-Marques, R. P. (2015). Nutritional parameters of Nellore heifers grazing in grass marandu receiving energy, protein and multiple supplement the dry-rainy transition period. Semina: Ciências Agrárias, 36(5), 3293-3302. doi: 10.5433/1679-0359.2015v36n5p3293

Reis, R. A., Ruggieri, A. C., Oliveira, A. A., Azenha, M. V., \& Casagrande, D. R. (2012). Suplementação como estratégia de produção de carne de qualidade em pastagens tropicais. Revista Brasileira de Saúde e Produção Animal, 13(3), 642655. doi: 10.1590/S1519-994020120003 00005

Silva, L. F. C., Valadares, S. C., Fo., Chizzotti, M. L., Rotta, P. P., Prados, L. F., Valadares, R. F. D., \& Braga, J. M. S. (2012). Creatinine excretion and relationship with body weight of Nellore cattle. Revista Brasileira de Zootecnia, 41(3), 807-810. doi: 10.15 90/S1516-35982012000300046

Tebot, I., Cajarville, C., Repetto, J. L., \& Cirio, A. (2012). Supplementation with non-fibrous carbohydrates reduced fiber digestibility and did not improve microbial protein synthesis in sheep fed fresh forage of two nutritive values. Animal, 6(4), 617-623. doi: 10.1017/S1751731111002011
Valadares, S. C., F., Marcondes, M. I., Chizzotti, M. R., \& Paulino, P. V. R. (2010). Exigências nutricionais de zebuinos puros e cruzados BR-CORTE (2a ed.). Viçosa, MG: UFV. doi: 10.5935/978-85-8179-111-1.2016B001

Valente, E. E. L., Paulino, M. F., Barros, L. V., Almeida, D. M., Martins, L. S., \& Cabral, C. H. A. (2014). Nutritional evaluation of young bulls on tropical pasture receiving supplements with different protein: carbohydrate ratios. Asian-Australasian Journal of Animal Sciences, 27(10), 14521460. doi: $10.5713 /$ ajas.2014.14085

Valente, E. E. L., Paulino, M. F., Detmann, E., Valadares, S. C., Fo., \& Lopes, S. A. (2013). Performance of young bulls supplemented with different relation of protein and carbohydrate from suckling phase until slaughter in tropical pasture. Journal of Animal and Plant Sciences, 18(2), 27112722.

Valente, T. N. P., Detmann, E., Queiroz, A. C., Valadares, S. C., Fo., Gomes, D. I., \& Figueiras, J. F. (2011). Evaluation of ruminal degradation profiles of forages using bags made from different textiles. Revista Brasileira de Zootecnia, 40(11), 2565-2573. doi: 10.1590/S1516-35982011001100039

Wanapat, M., Gunun, N., Gunun, P., \& Kang, S. (2013). Changes of rumen $\mathrm{pH}$, fermentation and microbial population as influenced by different ratios of roughage (rice straw) to concentrate in dairy steers. The Journal of Agricultural Science, 152(4), 1-11. doi: $10.1017 / S 0021859613000658$

Williams, C. H., David, D. J., \& lismaa, O. (1962). The determination of chromic oxide in faeces samples by atomic absorption spectrophotometry. The Journal of Agricultural Science, 59(3), 381-385. doi: $10.1017 / S 002185960001546 X$ 